Jurnal Ilmiah Ibnu Sina, 6(1), Maret 2021, 98-107

p-ISSN: 2502-647X; e-ISSN: 2503-1902

\title{
PENAMBATAN MOLEKULER SENYAWA CENDAWAN ENDOFIT Trichoderma sp. SEBAGAI INHIBITOR PROTEIN LOW DENSITY \\ LIPOPROTEIN, ENZIM LANASTEROL 14-A DEMETILASE DAN LIPASE YANG BERTANGGUNG JAWAB DALAM DERMATITIS SEBOROIK
}

\author{
Susi Susanti ${ }^{1}$, Eka Sukmawaty ${ }^{*}$, Masriany \\ Program Studi Biologi, Fakultas Sains dan Teknologi, Universitas Islam \\ NegeriAlauddin Makassar \\ *Email: ekasukmawaty@uin-alauddin.ac.id
}

Artikel diterima: 30 November2020; Disetujui: 27 Februari 2021

DOI: https://doi.org/10.36387/jiis.v6i1.636

\begin{abstract}
ABSTRAK
Dermatitis seboroik (DS) terjadi akibat produksi sebum yang berlebihan sehingga mengakibatkan pertumbuhan Mellasezia sp. di kulit menjadi tidak terkendali. Beberapa reseptor yang berperan dalam regulasi DS adalah protein Low Density Lipoprotein (LDL), enzim Lanasterol 14- $\alpha$ Demetylase, dan enzim Lipase. Penelitian ini bertujuan untuk mengetahui senyawa potensial cendawan endofit Trichoderma sp. sebagai antiseboroik dan mengetahui interaksi antar ligan sebagai inhibitor dalam regulasi DS. Penelitian dilakukan dengan penambatan molekuler berbasis komputer. Hasil penelitian menunjukkan bahwa terdapat dua senyawa kandidat inhibitor berdasarkan seleksi dengan nilai afinitas pengikatan yaitu Kloromisetin dan Benzil benzoat. Berdasarkan hasil docking dengan VINA autodock, senyawa yang potensial adalah Benzyl benzoate pada protein LDL dengan nilai afinitas pengikatan $-7,3 \mathrm{kkal} / \mathrm{mol}$, Senyawa tersebut adalah Kloromisetin pada enzim Lipase dengan nilai afinitas pengikatan -7,3 kkal / mol dan Lanasterol 14- Enzim $\alpha$ demetilase dengan nilai afinitas pengikatan -7,6 kkal / mol. Senyawa ini membentuk ikatan hidrogen dan ikatan hidrofobik. Berdasarkan prediksi Lipinski's rule offive, kedua senyawa tersebut efektif digunakan secara oral sebagai obat anti dermatitis seboroik.
\end{abstract}

Kata kunci: Dermatitis Seboroik, Cendawan Endofit, In Silico, Penambatan Molekuler.

\begin{abstract}
Seborrheic dermatitis (SD) occurs due to excessive sebum production resulting in the growth of the fungus Mellasezia sp. on the skin becomes uncontrollable. Some of the receptors that play a role in SD regulation are Low Density Lipoprotein (LDL) protein, Lanasterol 14- $\alpha$ Demetylase enzyme, and Lipase enzyme. This study aims to determine the potential compounds of the endophytic fungi Trichoderma sp. as an antiseborrheic and knowing the interaction between ligands as inhibitors in $S D$ regulation. The research was conducted with computer-based molecular docking. The results showed that there were two inhibitor candidate compounds based on the selection by binding affinity value, namely Chloromycetin and Benzyl
\end{abstract}


Jurnal Ilmiah Ibnu Sina, 6(1), Maret 2021, 98-107

p-ISSN: 2502-647X; e-ISSN: 2503-1902

benzoate. Based on the results of docking with VINA autodock, the potential compounds were Benzyl benzoate on LDL protein with binding affinity values of $7.3 \mathrm{kcal} / \mathrm{mol}$, compounds were Chloromycethin on Lipase enzyme with binding affinity values of $-7.3 \mathrm{kcal} / \mathrm{mol}$ and Lanasterol 14- $\alpha$ demethylase enzyme with a binding affinity value of $-7.6 \mathrm{kcal} / \mathrm{mol}$. These compounds form hydrogen bonds and hydrophobic bonds. Based on the prediction of Lipinski's rule of five, the two compounds are effective orally used as anti seborrheic dermatitis drugs.

Keywords: Seborrheic dermatitis, endophytic fungi, in silico, Molecular docking.

\section{PENDAHULUAN}

Indonesia merupakan negara yang beriklim tropis dengan keadaan suhu rata-rata $27^{\circ} \mathrm{C}$ sepanjang tahun. Pada musim kemarau, sebagian besar wilayah di Indonesia mencapai suhu 33-36 $6^{\circ}$. Suhu panas dapat memicu munculnya penyakit pada manusia seperti penyakit yang berhubungan dengan kulit seperti Seboroik. Dermatitis Seboroik (Picardo, 2014).

Penderita penyakit dermatitis Seboroik (DS) meresahkan banyak masyarakat karena tak hanya berdampak pada fisik tapi juga memberi dampak psikososial seperti malu untuk bertemu masyarakat umum dan merasa tidak percaya diri (Rahmatina, 2013). Dermatitis seboroik tidak hanya menyerang kepala namun juga dapat menyerang bagian tubuh lainnya. DS ini memberi efek peradangan, scaling, pengelupasan, pruritus dan munculnya eritema yang jelas. (Borda \& Wikramanayake, 2016). Persentase kasus kejadian dermatitis seboroik yang terjadi diseluruh dunia sebanyak $1-5 \%$ terhadap populasi dengan sistem imun yang kompeten (Nurhana, 2018).

Meningkatnya produksi Sebum dapat menginduksi proliferasi Melassezia sp. sehingga menyebabkan DS (Sanders et al., 2017). Mallasezia sp. merupakan jamur yang hidup sebagai flora normal pada kulit manusia namun dapat menyebabkan DS dalam keadaan pertumbuhan yang melebihi batas normal (Sihombing \& Saraswati, 2018).

Dermatitis Seboroik (DS) diregulasi oleh beberapa reseptor yaitu protein Low Density Lipoprotein (LDL) pada manusia yang menghasilkan Endothelin (ET-1) yang merangsang peningkatan proliferasi seboroik (Rachel et al., 2012). Selain 
Jurnal Ilmiah Ibnu Sina, 6(1), Maret 2021, 98-107

p-ISSN: 2502-647X; e-ISSN: 2503-1902

itu DS juga dipengaruhi oleh enzim

lipase dan Enzim lanasterol 14- $\alpha$ demethylase (Widaty \& Marina, 2016; Sihombing \& Saraswati, 2018).

Obat yang banyak digunakan untuk mengatasi penyakit ini adalah obat yang berfungsi sebagai anti seboroik. Beberapa senyawa yang terdapat dalam makhluk hidup mampu bertindak sebagai inhibitor seperti senyawa yang terkandung dalam fungi atau cendawan lain salah satunya dari cendawan endofit, seperti Trichoderma sp.

Berdasarkan hal tersebut maka di lakukanlah penelitian ini untuk mengetahui potensi senyawa dari cendawan endofit Trichoderma $\mathrm{sp}$. sebagai inhibitor penyakit dermatitis seboroik secara in silico.

\section{METODE PENELITIAN}

Penelitian ini menggunakan alat-alat berupa perangkat keras 1 set notebook dengan spesifikasi berupa Processor AMD A4-1200 dual-core $1 G H z, R A M$ 2GB DDR3, dan hardisk $500 G B$ dengan perangkat lunak sistem operasi Windows 8.1 with Bing, MGL Tools meliputi, PyRx 0.8 , Discovery Studio, PyMol viewer 1.1eval (visualisasi molekul) for Windows.

Struktur 3D reseptor di unduh $\begin{array}{lll}\text { melalui } & \text { situs }\end{array}$ (http://www.rscb.org/). yaitu Protein LDL (Low Density Lipoprotein) dengan kode identitas 2FCW. Enzim Lanasterol 14- $\alpha$ demetylase dengan kode identitas 4WMZ, dan Enzim Lipase dengan kode identitas 5GW8. Serta struktur 3D senyawa yang didapatkan dari hasil GC-MS ekstrak cendawan Trichoderma sp. yang diteliti oleh (Wahyuni, 2018) diunduh melalui situs https://pubchem.ncbi.nlm.nih.gov/ yaitu Benzaldehida, Phenol, Diethyl Pthalate, $n$-hexyl salicylate ss benzoid acid, octanal, Hexadecanoid acid, 9octadecanoid acid (z)-oleic acid, 1,2 Benzenedicarboxilic acid, Chloromycetin, Benzyl benzoate dan Benzoic acid.

\section{Preparasi reseptor}

Struktur 3D reseptor disimpan dalam file pdb kemudian di buka pada aplikasi Discovery Studio, dihilangkan atom hidrogen (polar only), molekul air dan juga ligan asli dari reseptor tersebut. File disimpan dalam bentuk file pdbqt. 
Jurnal Ilmiah Ibnu Sina, 6(1), Maret 2021, 98-107

p-ISSN: 2502-647X; e-ISSN: 2503-1902

Preparasi senyawa Trichoderma sp. sebagai ligan uji

Struktur 3D ligan yang disimpan bentuk file sdf. Dibuka pada aplikasi PyRx melalui open babel dan menambahkan ligan yang telah disimpan. Ukuran ligan di perkecil agar didapatkan struktur yang lebih stabil dengan mengklik minimize, convert to autodock ligan, dan siap untuk di tambatkan.

\section{Penambatan Ligan dengan Reseptor dengan Autodock Vina di PyRx}

Penambatan ligan pada sisi aktif reseptor di lakukan dengan program autodock vina atau Vina Wizard, yang diawali dengan menetapkan posisi gridbox, Dengan sendirinya program tersebut akan melakukan kalkulasi nilai perhitungan dari ligan dan reseptor. Kemudian validasi metode yang dilakukan untuk mengetahui hasil validasi terhadap ligan dan hasil docking. Digunakan parameter RMSD (Root Mean Square Deviation). Hasil docking yang menunjukkan nilai RMSD $<2$ dapat dikatakan bahwa docking tersebut valid.

\section{Visualisasi Data}

Hasil penambatan molekuler dapat divisualisasikan untuk menganalisis lebih lanjut dengan menggunakan aplikasi Discovery studio. Visualisasi dilakukan dengan mengubah file dari bentuk pdbqt menjadi pdb pada open babel agar dapat terbaca dalam aplikasi Discovery studio.

\section{Interpretasi Data}

Interpretasi data dilakukan dari hasil penambatan pada sisi aktif, yang meliputi nilai scoring energi ikatan yang di prediksi paling dekat dengan kofaktor reseptor yang berperan pada DS dan mengikat asam amino protein pada binding site (sisi pengikatan) reseptor. Interaksi ligan dengan reseptor diketahui melalui aplikai PyMOL dan discovery studio kemudian dilakukan uji Prediksi Lipinski rule of five untuk mengetahui potensinya digunakan secara intraseluler.

\section{HASIL DAN PEMBAHASAN}

Analisis potensi senyawa

\section{Trichoderma sp.}

Hasil penambatan dari autodock vina kemudian dilakukan validasi hasil. Penambatan yang memiliki nilai 
Jurnal Ilmiah Ibnu Sina, 6(1), Maret 2021, 98-107

p-ISSN: 2502-647X; e-ISSN: 2503-1902

RMSD (Root Mean Square tidak stabil kompleks yang terbentuk Deviation) < 2 memiliki tingkat (Fikry, 2014). Berdasarkan hasil validasi yang terbaik. Hal tersebut penelitian, nilai $\Delta$ Gbind yang berkaitan dengan hasil signifikansi diperoleh kurang lebih sama dengan apabila dilakukan pengulangan docking atau penambatan maka standar yang ditetapkan sehingga prediksi ikatan yang terjadi tidak berbeda jauh dengan hasil docking sebelumnya (Yanuar, 2012). Adapun nilai hasil penambatan senyawa terhadap ketiga reseptor dengan nilai RMSD $<2$ terlihat pada tabel 1. Semakin rendah nilai energi ikatan maka semakin stabil pelekatan ligan dengan reseptor sedangkan semakin kompleks yang dihasilkan stabil. Selain itu, nilai energi ikatan ligan uji lebih kecil atau lebih potensial dibanding dengan ligan kontrol. Berdasarkan analisis nilai $\Delta G b i n d$ protein low density lipoprotein dan Enzim Lanasterol 14- $\alpha$ Demetilase, senyawa dengan nilai potensial yaitu Benzyl benzoate dan Chloromycetin dibanding dengan ligan kontrol. besar nilai energi ikatan maka semakin

Tabel 1. Nilai energi ikatan $\Delta$ Gbind $(\mathrm{kkal} / \mathrm{mol})$ dari hasil penambatan molekuler

\begin{tabular}{llll}
\hline \multicolumn{1}{c}{ Ligan } & \multicolumn{3}{c}{ Binding Affinity (kkal/mol) } \\
\cline { 2 - 4 } & $\begin{array}{l}\text { LDL (Low Density } \\
\text { Lipoprotein) }\end{array}$ & $\begin{array}{l}\text { Lanasterol 14- } \boldsymbol{\alpha} \\
\text { demetylase }\end{array}$ & \multicolumn{1}{c}{ Lipas } \\
\hline Benzaldehida & -4.6 & -5.2 & -4.5 \\
Phenol & -4.6 & -4.8 & -4.3 \\
Diethyl phthalate & -6.4 & -6.3 & -4.9 \\
N-hexyl salicylate & -5.9 & -6.1 & -5.1 \\
Octanal & -4.3 & -5.1 & -4.0 \\
Hexadecanoic acid & -5.7 & -6.5 & -5.5 \\
Oleic acid & -5.5 & -6.5 & -3.9 \\
1,2 Benzenedicarboxilic & -5.9 & -5.9 & -6.1 \\
acid & $-7.0 *$ & $-7.6 *$ & $-7.3 *$ \\
Chloromycethin & $-7.3 *$ & $-7.5 *$ & $-7.0^{*}$ \\
Benzyl Benzoate & -5.1 & -5.6 & -4.9 \\
Benzoic acid & -4.1 & - & - \\
2-methyl-2,4-pentanadiol & & -7.6 & - \\
(kontrol) & - & - & -6.6 \\
Flucanazole (kontrol) & - & & \\
2-acetamido-2-deoxy-beta- & - & & \\
D-glucopyranos (kontrol) & & &
\end{tabular}


Jurnal Ilmiah Ibnu Sina, 6(1), Maret 2021, 98-107

p-ISSN: 2502-647X; e-ISSN: 2503-1902

Tabel 2. Interaksi ligan dari cendawan endofit Trichoderma sp. dengan reseptor dermatitis seboroik

\begin{tabular}{|c|c|c|c|c|}
\hline Ligan - protein & Interaksi ligan dan reseptor & Residu & $\begin{array}{c}\text { Tipe } \\
\text { pengikatan }\end{array}$ & $\begin{array}{c}\text { Jarak } \\
(\AA)\end{array}$ \\
\hline $\begin{array}{l}\text { Benzyl benzoate } \\
\text { dan } L D L\end{array}$ & 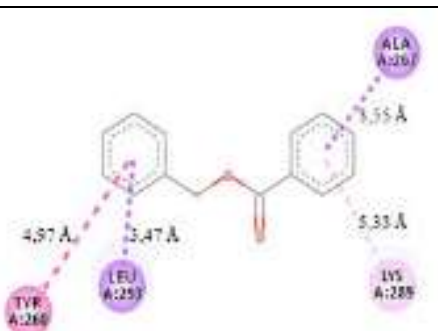 & $\begin{array}{l}\text { ALA A:267 } \\
\text { LEU A:293 } \\
\text { TYR A:260 } \\
\text { LYS A:289 }\end{array}$ & $\begin{array}{l}\text { Hidrofobik } \\
\text { Hidrofobik } \\
\text { Hidrofobik } \\
\text { Hidrofobik }\end{array}$ & $\begin{array}{l}3.55 \\
3.47 \\
4.97 \\
5.33\end{array}$ \\
\hline $\begin{array}{l}\text { Chloromycetin } \\
\text { dan } L D L\end{array}$ & (4.2) & $\begin{array}{l}\text { ASP B:151 } \\
\text { ALA A:267 } \\
\text { ARG A:296 } \\
\text { LEU A:293 } \\
\text { ALA A:267 }\end{array}$ & $\begin{array}{l}\text { Hidrogen } \\
\text { Hidrogen } \\
\text { Hidrogen } \\
\text { Hidrofobik } \\
\text { Hidrofobik }\end{array}$ & $\begin{array}{l}2.15 \\
3.27 \\
3.06 \\
3.40 \\
5.18\end{array}$ \\
\hline $\begin{array}{l}\text { Benzyl Benzoat } \\
\text { dan Lanasterol } \\
\text { 14- } \alpha \text { demetilase }\end{array}$ & 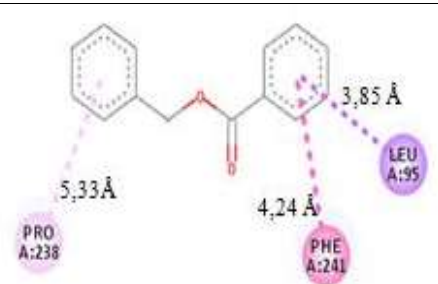 & $\begin{array}{l}\text { LEU A:95 } \\
\text { PHE A:241 } \\
\text { PRO A:238 }\end{array}$ & $\begin{array}{l}\text { Hidrofobik } \\
\text { Hidrofobik } \\
\text { Hidrofobik }\end{array}$ & $\begin{array}{l}3.85 \\
4.24 \\
5.33\end{array}$ \\
\hline
\end{tabular}

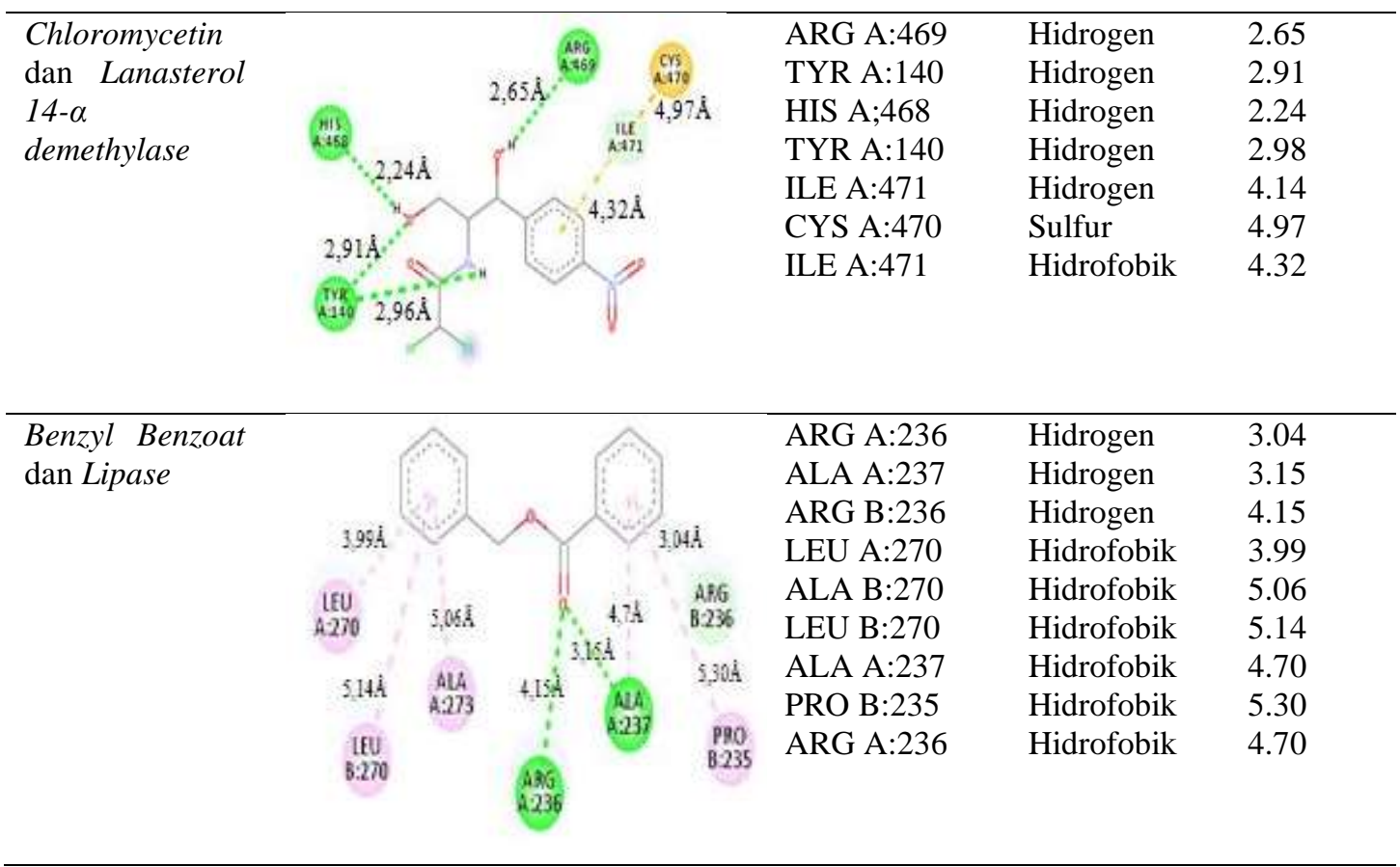


Jurnal Ilmiah Ibnu Sina, 6(1), Maret 2021, 98-107

p-ISSN: 2502-647X; e-ISSN: 2503-1902

\begin{tabular}{|c|c|c|c|c|}
\hline Ligan - protein & Interaksi ligan dan reseptor & Residu & $\begin{array}{c}\text { Tipe } \\
\text { pengikatan }\end{array}$ & $\begin{array}{c}\text { Jarak } \\
(\AA)\end{array}$ \\
\hline $\begin{array}{l}\text { Chloromycetin } \\
\text { dan Lipase }\end{array}$ & (212) & $\begin{array}{l}\text { ALA B:273 } \\
\text { ARG A:274 } \\
\text { ARG A: } 274 \\
\text { ARG B:274 } \\
\text { ARG B:274 } \\
\text { ARG A:236 } \\
\text { ALA A: } 237 \\
\text { ARG B:236 } \\
\text { ALA A: } 237\end{array}$ & $\begin{array}{l}\text { Hidrogen } \\
\text { Hidrogen } \\
\text { Hidrogen } \\
\text { Hidrogen } \\
\text { Hidrogen } \\
\text { Hidrofobik } \\
\text { Hidrofobik } \\
\text { Hidrofobik } \\
\text { Hidrofobik }\end{array}$ & $\begin{array}{l}2.51 \\
2.96 \\
3.02 \\
3.08 \\
2.88 \\
5.00 \\
4.65 \\
4.90 \\
4.20\end{array}$ \\
\hline
\end{tabular}

\section{Interaksi ligan dengan reseptor}

Semua hasil penambatan dengan nilai terbaik kemudian disimpan dalam bentuk file pdbqt. Kemudian dilanjutkan ketahap selanjutnya untuk mengetahui bagian atau posisi orientasi ligan yang telah ditambatkan pada makromolekul atau reseptor serta untuk mengetahui jarak antara ikatan ligan dengan asam amino yang terikat. Tahap ini dikerjakan pada software aplikasi PyMol. Kemudian dilanjutkan dengan menggunakan aplikasi Discovery studio untuk melihat interaksi ligan dengan reseptor. interaksi yang terjadi terlihat pada tabel 2

Interaksi yang terjadi pada ligan dan reseptor apabila diikat oleh ikatan hidrogen maka akan menunjukkan adanya kekuatan antar ikatan. Dan semakin kecil jarak ikatan hidrogen antara ligan dengan reseptor maka semakin besar kekuatan afinitasnya. Keberadaan ikatan hidrogen mampu mempengaruhi sifat kimia-fisika dari suatu senyawa seperti sifat kelarutan dalam air, titik didih, titik lebur serta kemampuannya dalam membentuk asam. Perubahan sifat senyawa tersebut dapat mempengaruhi sifat dan aktivitas biologis dari suatu senyawa (Beny et al., 2020) Selain itu, keberadaan ikatan hidrofobik mampu menaikkan stabilitas protein dengan mengubah asam amino yang bersifat hidrofilik dalam lingkungan hidrofobik serta mampu menentukan residu asam amino yang berkontribusi secara signifikan untuk menjaga kestabilan protein (Malau \& Sianturi, 2019).

Susi Susanti, dkk | 104 
Jurnal Ilmiah Ibnu Sina, 6(1), Maret 2021, 98-107

p-ISSN: 2502-647X; e-ISSN: 2503-1902

\section{Prediksi Lipinski Rule of Five}

Aturan yang telah ditetapkan dalam Lipinski rule digunakan dalam memprediksi fisikokimia dari ligan dengan menentukan sifat hidrofobik/hidrofilik pada senyawa untuk bisa masuk kedalam membran sel melalui difusi pasif (Karim, 2018). Syarat-syarat yang harus terpenuhi dalam menentukan senyawa kandidat molekul obat yang telah ditetapkan dalam Lipinski rule yaitu berat molekul $<500$ Da agar mudah masuk dan menembus membran sel, senyawa yang lebih dari ketetapan tidak mampu dalam berdifusi kedalam sel, nilai Log $\mathrm{P}<5$ agar selektif dalam mengikat protein target, semakin rendah nilai
Log P maka semakin baik dan mudah larut dalam air Senyawa akan bersifat hidrofobik ketika memiliki nilai Log P yang semakin tinggi. Semakin tinggi sifat hidrofobik maka cenderung memiliki sifat toksik yang lebih tinggi dan kurang selektif dalam mengikat protein/enzim target, hal tersebut disebabkan karena senyawa ini akan tersimpan lebih lama dan berdistribusi lebih luas pada lipid bilayer, jumlah ikatan hidrogen donor $<5$, Jumlah ikatan hidrogen akseptor $<10$ dan Reaktif molar : 40-130 (Karim, 2018). Berdasarkan aturan tersebut maka senyawa dari cendawan Trichoderma sp. diuraikan dalam tabel 3

Tabel 3. Prediksi Lipinski Rule of Five senyawa Benzyl benzoate dan

Chloromycetin

\begin{tabular}{cccccc}
\hline Ligan & $\begin{array}{c}\text { Berat } \\
\text { Molekul } \\
\text { (Da) }\end{array}$ & $\begin{array}{c}\text { Jumlah } \\
\text { Ikatan } \\
\text { Hidrogen- } \\
\text { Donor }\end{array}$ & $\begin{array}{c}\text { Jumlah } \\
\text { Ikatan } \\
\text { Hidrogen } \\
\text { Aseptor }\end{array}$ & $\begin{array}{c}\text { Molar } \\
\text { refractivity }\end{array}$ & Log P \\
\hline Benzyl benzoate & 200 & 0 & 2 & 48.895996 & 0.477880 \\
\hline Chloromycetin & 314 & 3 & 6 & 64.355698 & -0.200590 \\
\hline
\end{tabular}

Berdasarkan hasil analisis, berdifusi pasif kedalam sel serta dapat diketahui bahwa kedua senyawa yang dikonsumsi secara oral.

digunakan sebagai ligan, memenuhi standar Lipinski yang telah ditetapkan,

\section{KESIMPULAN}

Berdasarkan hasil penambatan molekuler yang telah dilakukan 
Jurnal Ilmiah Ibnu Sina, 6(1), Maret 2021, 98-107

p-ISSN: 2502-647X; e-ISSN: 2503-1902

diketahui senyawa dari cendawan endofit Trichoderma sp yang berpotensi sebagai kandidat obat terhadap tiga reseptor yang berregulasi dalam dermatitis seboroik (DS) yaitu Chloromycetin dan Benzyl benzoate Interaksi yang terbentuk dengan adanya ikatan hidrogen dan ikatan hidrofobik. Berdasarkan prediksi Lipinski rule of five dari kedua senyawa tersebut telah memenuhi ketetapan Lipinski yang menujukkan bahwa senyawa tersebut mampu berdifusi ke dalam sel dan dapat dikonsumsi secara oral.

\section{DAFTAR PUSTAKA}

Beny, R., Yana, N. R. A., \& Leorita, M. (2020). Desain Turunan Senyawa Leonurine Sebagai Kandidat Obat Anti Inflamasi. Jurnal Farmasi Galenika (Galenika Journal of Pharmacy) (e-Journal), 6(1), 181-191. https://doi.org/10.22487/j2442 8744.2020.v6.i1.15025

Borda, L. J., \& Wikramanayake, T. C. (2016). Seborrheic Dermatitis and Dandruff:

A Comprehensive Review. J Clin Investig Dermatol, 3(2), 1-22.

Gulwe, A. B., Mishra, D. N., \& Gomare, K. S. (2020). Docking studies of lipase (Mflip1) from malassezia furfur (Robin) with propanamide, N-methyl-2- amino and 1-propanol, 3(dimethylamino) predicting inhibitory activity. International Journal of Pharmaceutical Research, 12(1), 899-903. https://doi.org/10.31838/ijpr/2 020.12.01.011

Karim, M. Al. (2018). Analisis Docking Molekuler Senyawa Dlavonoid dan Steroid terhadap Enzim Siklooksigenase dan Fosfolipase [Fakultas Farmasi Universitas Setia Budi Surakarta 2018]. In Skripsi. https://doi.org/10.1017/CBO9 781107415324.004

Malau, N. D., \& Sianturi, M. (2019). Analisa Interaksi Hidrofobik terhadap Kestabilan Termal Enzim Xilanase Aspergillus niger. 3(2), 215-227.

Nurhana, A. (2018). Deteksi Spesies Malassezia Pada Pasien Pityriasis Versikolor Dan Dermatitis Seboroik Dengan Menggunakan Nested-PCR Di RSUP Dr. Wahidin Sudirohusodo Dan Rs Jejaring Di Makassar Tahun 2018. Program Pendidikan Dokter Spesialis-1 (Sp.1) Program Studi Ilmu Kesehatan Kulit Dan Kelamin Fakultas Kedokteran Universitas Hasanuddin Makassar.

Picardo, M., Cameli, N. (2014). Evidence-based dermatology. BMJ Publishing Group.

Rachel, S., Djuanda, S., Novianto, E., \& Boediardja, S. A. (2012). Peran stres oksidatif pada penuaan kulit secara intrinsik. 
Jurnal Ilmiah Ibnu Sina, 6(1), Maret 2021, 98-107

p-ISSN: 2502-647X; e-ISSN: 2503-1902

MDVI, 39(3), 127-133.

Rahmatina. (2013). Uji Validitas dan Reabilitas Dermatology Life Quality Index (DLQI) Berbahasa Indonesia Pada Pasien Piliklinik Ilmu Kesehatan Kulit dan Kelamin Rumah Sakit Dr. Cipto Mangunkusumo. Fakultas Kedokteran Universitas Indonesia Program Pendidikan Kedokteran Spesialis Ilmu Kesehatan Kulit dan Kelamin.

Sanders, M. G. H., Pardo, L. M., Franco, O.H. Ginger, R. S., \& Nijsten, T. . (2017). Prevalence and determinants of seborrheic dermatitis in a middle aged and elderly population: the Rotterdam Study. the Rotterdam study. $\mathrm{Br} \quad J$ Dermatol, 148(53), 1-15. https://doi.org/10.1111/ijlh.12 426

Sihombing, M. A., \& Saraswati, I. (2018). Uji Efektivitas Antijamur Ekstrak Biji Pepaya ( Carica Papaya L .) Terhadap Pertumbuhan Malassezia Furfur Secara In Vitro. Jurnal Kedokteran Diponegoro, 7(2), 724-732.

Wahyuni, S. (2018). Skrining Fitokimia, Kadar Total Fenol, dan Analisa Senyawa dengan GC-MS (Gass CromatografyMass Spektroskopy) Cendawan Endofit Penghasil Antioksidan. In Skripsi. Program Studi Biologi, Fakultas Sains dan Teknologi, Universitas Islam Negeri Alauddin Makassar.

Widaty, S., \& Marina, A. (2016).
Pilihan Pengobatan Jangka Panjang Pada Dermatitis Seboroik. MDVI, 43(4), 153159.

Yanuar, A. (2012). Penambatan Molekuler. Praktek dan aplikasi pada virtual screening. Fakultas Farmasi Universitas Indonesia. 